Published in "International Journal of Hospitality Management", 2019, vol. 78, pp. 47-49, which should be cited to refer to this work.

DOI : $10.1016 / j . i j h m .2018 .11 .013$

\title{
A macroeconomic perspective on Airbnb's global presence
}

A Research Paper Published In

International Journal of Hospitality Management (2019), 78, 47-49

\section{Cindy Yoonjoung Heo}

Associate Professor

Ecole hôtelière de Lausanne

HES-SO/University of Applied Sciences Western Switzerland

Lausanne, Switzerland.

Phone: (41) 217851831

E-mail: cindy.heo@ehl.ch

\section{Isabella Blengini}

Assistant Professor

Ecole hôtelière de Lausanne

HES-SO/University of Applied Sciences Western Switzerland

Lausanne, Switzerland.

Phone: (41) 217851991

E-mail: isabella.blengini@ehl.ch

Corresponding Author: Cindy Yoonjoung Heo 


\section{A macroeconomic perspective on Airbnb's global presence}

\section{Introduction.}

The peer to peer (P2P) economy, also known as the collaborative economy or the sharing economy, has attracted a great deal of attention from scholars in the tourism field, because business platforms based on this concept are experiencing explosive growth. Although human beings have always shared, the novelty of the P2P economy consists in "sharing with strangers" (Schor, 2014). In tourism, start-ups based on the P2P economy concept have swept across the globe triggering claims that the $\mathrm{P} 2 \mathrm{P}$ economy is disrupting the traditional tourism industry (Heo, 2016; Zervas, Proserpio, \& Byers, 2017). A noticeable example of the P2P economy in the tourism industry is demonstrated by Airbnb, which enables owners to offer their unoccupied houses or rooms for short-term rental. Airbnb offers more than four million global listings across 191 countries and over 200 million total guests have used an Airbnb accommodation around the world since the company's founding in 2008. (Airbnb, 2017).

Academic investigation regarding $\mathrm{P} 2 \mathrm{P}$ accommodation rentals has recently emerged and seems to be moving in several different directions (Benoit et al., 2016). Identifying motivations for participating and satisfaction factors in renting a P2P accommodation was one of the most researched areas (e.g., Belarmino et al., 2017; Karlsson \& Dolnicar, 2016; Möhlmann, 2015; So, Oh, \& Min, 2018; Tussyadiah, 2016; Tussyadiah \& Pesonen, 2016). While financial benefit (i.e., cost saving) is often seen as the most important motivator, authenticity and experiential value (i.e., interaction between host and guest) have also been found to be important drivers. (Tussyadiah \& Pesonen, 2016; Guttentag, 2015; Guttentag et al., 2018). Accommodation amenities, space and location have additionally been found to be important motivations (e.g., Quinby \& Gasdia, 2014). Böcker and Meelen (2017) argued that it is likely that motivations to participate in the P2P economy are different depending on demographic groups.

Other scholars analyzed the unique aspects of the P2P transaction for accommodation rentals. In particular, several studies highlighted the importance of trust between participants, both in relation to the platform being used and other users, in P2P transactions. Establishing trust between guest and host helps manage the inherent uncertainty surrounding P2P transactions. As such, trust is a key prerequisite for the success of P2P transactions (Ma et al., 2017). Ert, Fleischer, and Magen (2016) contend that guests infer the host's trustworthiness from the host's profile photos, and that their choice is affected by this inference. Their study found that the more trustworthy the host is perceived to be from the host's profile photo, the higher the price of the listing and the probability of being rented. On the other hand, Liang, Choi, and Joppe (2017)'s study showed that perceived risk negatively impacts Airbnb guests' perceived value and repurchase intention while perceived value positively enhances their repurchase intention.

Other researchers explored the impact of $\mathrm{P} 2 \mathrm{P}$ accommodation rental in the tourism and hospitality industry (Zervas et al., 2017; Xie \& Kwok, 2017). For example, Zervas et al. 
(2017) found that hotels that do not cater to business travelers and lower-end hotels are more heavily affected, relative to high-end lodging options, by Airbnb. Blal et al. (2018) studied the longitudinal impact of Airbnb on hotel sales performance in San Francisco and found that Airbnb supply does not affect hotel sales indicating a supplementary effect, but average price of Airbnb listings affects hotel RevPAR (Revenue Per Available Room) positively. On the other hand, Tussyadiah and Pesonen (2016) suggested that the use of P2P accommodations might affect not only the hospitality industry, but also consumers' travel patterns.

Although several studies tried to measure it by different metrics from a macroeconomic perspective, there is no central source of information on the size of the P2P economy (Calo \& Rosenblat, 2017). Further, most academic research has explored Airbnb from a micro perspective, such as participants' motivation and behaviors. The rise of the P2P economy has been fueled by a range of social, economic and technological factors, but limited research has been focused on the $\mathrm{P} 2 \mathrm{P}$ economy from a macroeconomic perspective. Therefore this study tried to identify the macroeconomic factors affecting Airbnb's global presence.

\section{Data and results}

The objective of this study is to understand which macroeconomic factors cause local residents (i.e., Airbnb hosts) to take part in the Airbnb rental market. More specifically, we used - as an endogenous variable - the number of Airbnb rental listings classified as "entire home", "private room" and "shared room" while we employed various socioeconomic variables as exogenous variables.

First, we identified the 100 most populous countries, which include developing as well as developed countries, and their capital cities in order to find the total number of Airbnb listings. We retrieved the number of Airbnb rentals in December 2017 from Airdna, a thirdparty Airbnb database organization. Nevertheless, it is worth mentioning that data were not available for several cities (e.g., Pyongyang in North Korea, Baghdad in Iran, Tehran in Iraq, etc.).

Second, in order to explain the number of rentals available in different capitals, we considered several macroeconomic factors, such as countries' degree of technological development, economic size, the relative size of the tourism and travel industries, tourist arrivals, nominal exchange rate, the average level of economic development (or well-being), and their productivity level. In general, we assumed that Airbnb is more widespread in countries where people are very comfortable using technology. We used countries' economic size because we know that the bigger the country the more it attracts tourists. To better characterize economic conditions, we also included the average well-being and the level of productivity. The exchange rate is another important variable because it gives us a measure of the competitiveness of the country at the international level. Finally, we included international arrivals and the size of the tourism industry because they give us a measure of the degree of openness of the country. We applied a stepwise regression approach to analyze some key variables including the Global Peace Index (GPI), which measures the relative position of 
nations' and regions' peacefulness and the Global Competitiveness index, which is a measure of a country's development including several factors such as institutions, infrastructure, macroeconomic environment, health and education. However, those variables have been excluded from the final analysis because they were not significant.

All data for exogenous variables were observed in 2016, and the log transformation was applied. The measure of technological development is the 2016 ICT development index (IDI), issued by the International Telecommunication Unit of the United Nations. The IDI, which has been published annually since 2009, is a composite index that combines 11 indicators into one benchmark measure. It has been used to monitor and compare developments in information and communication technology (ICT) between countries and over time. In order to control for inflation, we used real variables. Real Gross Domestic Product (GDP) proxies the economic size of a country and is measured in constant 2010 US\$, while the size of the tourism and travel industries is measured as these industries' value added as a percentage of total GDP. GDP in constant 2010 US\$ is a measure of 2016 real GDP, under the assumption that prices in all the countries were the same. Separately, we controlled for inflation and our analysis showed that inflation does not significantly affect Airbnb rentals. We followed the same logic also for GDP per capita and GDP per worker. GDP per capita measures the level of economic development of the country, while GDP per employed person is used as a proxy for productivity. GDP per capita and GDP per employed person are also real variables expressed in constant 2011 PPP international dollars. The way in which these two variables are measured allows to control for the different costs of living and price levels, relative to the US dollar.

Finally, the nominal exchange rate is defined as the number of units of local currency necessary to buy one US dollar. Table 1 shows the list of variables with their sources.

Table 1. Variable Definitions and Sources

\begin{tabular}{lll}
\hline Variable & Definition & Source \\
\hline Total rentals & $\begin{array}{l}\text { The total number of rentals on Airbnb } \\
\text { including entire houses, private rooms, } \\
\text { and shared rooms }\end{array}$ & Airdna.com \\
\hline IDI & Technological development index & $\begin{array}{l}\text { International } \\
\text { Telecommunication Unit } \\
\text { of the United Nations }\end{array}$ \\
\hline Tourism and & Tourism and travel contribution as a & World Bank \\
Travel/GDP & percentage of total GDP & \\
\hline GDP & GDP in constant 2010 US\$ & World Bank \\
\hline Intl Arrivals & Tourist Arrivals in 2015 & World Bank \\
\hline Exchange rate & Units of local currency per US\$ & World Bank \\
\hline GDP per capita & In constant 2011 PPP international \$ & World Bank \\
\hline GDP per worker & In constant 2011 PPP international \$ & World Bank \\
\hline
\end{tabular}

Table 2 exhibits the results of the regression analysis. The total number of listings is positively correlated with the technological development index, the contribution of trade and tourism to GDP, the nominal exchange rate and negatively with GDP per employed person. 
Airbnb is more popular in countries where the population is technologically savvy. Another significant variable is represented by the relative size of the tourism and trade industries in the country: If those industries are large relative to total GDP, we observe a higher presence of Airbnb. The results suggest that a country that is highly oriented towards tourism will be more familiar with this type of platform. An increase in the nominal exchange rate increases Airbnb presence. According to our definition, an increase in the exchange rate means that the local currency is becoming cheaper with respect to the dollar. This variable might thus be interpreted as a measure of a country's international competitiveness: A more depreciated currency might attract international tourists. And in fact, this study found that as the local currency becomes cheaper, the number of rentals increases. Finally, we found that a higher level of productivity in the country, measured by GDP per worker, reduces Airbnb listings. The higher the productivity of workers, the higher their share of GDP, which can be considered their labor income. We can thus interpret this result by saying that in a country where labor income is high, the need to use Airbnb may be lower. More intuitively, if labor income is low, people will have more incentive to rent their property as a source of additional revenue. These results are, in general, confirmed for all other endogenous variables. However, when it comes to private room rentals, international arrivals and GDP become significant. If, instead, we consider specifically "entire house" and "shared room" the contribution of tourism to GDP stops being significant.

Table 2. Regression Results

\begin{tabular}{ccccc}
\hline & $(1)$ & $(2)$ & $(3)$ & $(4)$ \\
\cline { 2 - 5 } & Total rentals & Entire house & Private room & Shared room \\
\hline \multirow{2}{*}{ IDI } & $3.82^{* * *}$ & $4.05^{* * *}$ & $2.94^{* * *}$ & $2.93^{* * *}$ \\
& $(4.37)$ & $(4.54)$ & $(3.91)$ & $(3.36)$ \\
\hline Tourism/ & $0.94^{*}$ & 0.83 & $0.79^{*}$ & -0.10 \\
GDP & $(1.81)$ & $(1.56)$ & $(1.73)$ & $(-0.24)$ \\
\hline \multirow{2}{*}{ GDP } & 0.32 & 0.23 & $0.34 *$ & 0.24 \\
& $(1.42)$ & $(0.99)$ & $(1.70)$ & $(1.33)$ \\
\hline Intl & 0.29 & 0.31 & $0.43^{*}$ & $0.63^{* * *}$ \\
arrivals & $(1.10)$ & $(1.16)$ & $(1.88)$ & $(3.06)$ \\
\hline Exchange & $0.16^{*}$ & $0.18^{*}$ & $0.17^{* *}$ & $0.20^{* * *}$ \\
rate & $(1.79)$ & $(1.98)$ & $(2.17)$ & $(3.06)$ \\
\hline GDP per & 0.02 & 0.04 & 0.00 & 0.08 \\
capita & $(0.10)$ & $(0.28)$ & $(0.03)$ & $(0.68)$ \\
\hline GDP per & $-1.16^{* *}$ & $-0.94 *$ & $-1.19^{* * *}$ & $-1.28^{* *}$ \\
worker & $(-2.39)$ & $(-1.90)$ & $(-2.86)$ & $(-2.62)$ \\
\hline \multirow{2}{*}{ cons } & -2.58 & -3.60 & -3.94 & -4.66 \\
& $(-0.56)$ & $(-0.76)$ & $(-0.99)$ & $(-1.12)$ \\
\hline$N$ & 59 & 59 & 58 & 49 \\
\hline$R^{2}$ & 0.68 & 0.70 & 0.69 & 0.69 \\
\hline
\end{tabular}

Note: $t$ statistics are in parentheses. ${ }^{*} \mathrm{p}<0.10,{ }^{* *} \mathrm{p}<0.05,{ }^{* * *} \mathrm{p}<0.01$ 


\section{Discussion and conclusions}

This analysis tried to identify how macroeconomic factors are related to the number of Airbnb rental listings. The findings of this study revealed that the level of technological development in a given country is the most important factor affecting the number of Airbnb listings. Another interesting finding is the negative relationship between GDP per worker and the number of Airbnb listings. In addition, international arrivals are highly related to private room rentals, but not to entire houses. Future research may explore this issue further.

To the best of our knowledge, this study is the first to investigate the factors influencing Airbnb's global presence at the macroeconomic level. However, several limitations of the present study should be noted. First, although we tried to include as many variables as possible, there could be other meaningful variables related to the number of Airbnb listings. It would be interesting to explore the relationship with the real estate market. Second, due to limited data availability, we conducted a cross-sectional analysis. Future research should extend the scope of the study not only by including new variables but also by introducing a temporal dimension to the analysis. Cultural factors, legal issues, financial development or residents' attitude can be considered for future researchers to study. Garau-Vadell, GutiérrezTaño, and Díaz-Armas (2018) found that residents' support for P2P accommodation is directly and positively affected by their perception of the social and cultural impacts, and especially by the economic impacts.

Exploring the impacts of $\mathrm{P} 2 \mathrm{P}$ businesses on macroeconomic dynamics would be another interesting area to study. Fang, Ye, and Law (2016) tried to evaluate the effect of the entry of Airbnb on employment in the local tourism industry. The results of their study suggest that the entry of Airbnb benefits the entire tourism industry by generating new jobs. The marginal effect decreases as the size of the P2P economy increases. More research on the impact of the $\mathrm{P} 2 \mathrm{P}$ economy may guide regulators. Currently most regulations on $\mathrm{P} 2 \mathrm{P}$ accommodation sharing apply identical rules regardless of property type (i.e., entire house, private room and shared room). We believe that the differential impacts of each property type on tourism demand, hotel industry, and local economy should be studied and different regulations for each property type may need to be enforced. Furthermore, when calculating the tourism multiplier effect, the revenue generated by $\mathrm{P} 2 \mathrm{P}$ accommodation sharing should be included.

Given the legal and regulatory issues concerning the P2P economy, it is important for academic researchers to observe ongoing changes and to apply various perspectives and theories for a deeper and richer understanding of the phenomenon. An understanding of how $\mathrm{P} 2 \mathrm{P}$ businesses fit in the macroeconomic landscape will allow local governments and destination management organizations to develop policies and actions regarding $\mathrm{P} 2 \mathrm{P}$ business models aiming at minimizing the cost and maximizing the benefits to the local community. Further, we encourage future researchers to study the non-economic impacts of P2P businesses on local communities by adopting qualitative research methods. 


\section{References}

Airbnb (2017, August 7). Fast Facts. Retrieved from https://press.atairbnb.com/app/uploads/2017/08/4-Million-Listings-Announcement1.pdf

Blal, I., Singal, M., \& Templin, J. (2018). Airbnb's effect on hotel sales growth. International Journal of Hospitality Management, 73, 85-92.

Böcker, L., \& Meelen, T. (2017). Sharing for people, planet or profit? Analysing motivations for intended sharing economy participation. Environmental Innovation and Societal Transitions, 23, 28-39.

Calo, R., \& Rosenblat, A. (2017). The taking economy: Uber, information, and power. Columbia Law Review, 117, Retrieved from https://papers.ssrn.com/sol3/papers.cfm?abstract id=2929643

Ert, E., Fleischer, A., \& Magen, N. (2016). Trust and reputation in the sharing economy: The case of Airbnb. Tourism Management, 55, 62-73.

Fang, B., Ye, Q., \& Law, R. (2016). Effect of sharing economy on tourism industry employment. Annals of Tourism Research, 57, 264-267.

Garau-Vadell, J. B., Gutierrez-Taño, D., Diaz-Armas, R. (2018). Residents's support for P2P accommodation in mass tourism destinations. Journal of Travel Research, Advance online publication. doi: 10.1177/0047287518767067.

Guttentag, D. (2015). Airbnb: destructive innovation and the rise of an informal tourism accommodation section in Tourism. Current Issues in Tourism, 18(12), 1192-1217.

Guttentag, D., Smith, S., Potwarka, L., \& Havitz, M. (2018). Why tourists choose Airbnb: A motivation-based segmentation study. Journal of Travel Research. 57(3), 342-359.

Heo, Y. J. (2016). Sharing economy and prospects in tourism research. Annals of Tourism Research, 58, 166-170.

Ma, X., Hancock, J. T., Lim Mingjie, K., \& Naaman, M. (2017). Self-disclosure and perceived trustworthiness of Airbnb host profiles. Presented at the 2017 ACM Conference on Computer Supported Cooperative Work and Social Computing, CSCW '17, New York, NY, USA: ACM.

Möhlmann. M. (2015). Collaborative consumption: Determinants of satisfaction and the likelihood of using a sharing economy option again. Journal of Consumer Behaviour, 14, 193-207.

Karlsson, L., \& Dolnicar, S. (2016). Someone's been sleeping in my bed. Annals of Tourism Research, 58(C), 159-162.

Liang, L. J., Choi, H. C., \& Joppe, M. (2017). Understanding repurchase intention of Airbnb 
consumers: Perceived authenticity, electronic word-of-mouth, and price sensitivity. Journal of Travel \& Tourism Marketing, 1-17.

Liu, S. Q., \& Mattila, A. S. (2017). Airbnb: Online targeted advertising, sense of power, and consumer decisions. International Journal of Hospitality Management, 60, $33-41$.

Schor, J. (2014). Devating the sharing economy. Great Transition Initiative. Retrieved from http://greattransition.org/publication/debating-the-sharing-economy

Tussyadiah, I. P. (2016). Factors of satisfaction and intention to use peer-to-peer accommodation. International Journal of Hospitality Management, 55, 70-80.

Tussyadiah, I. P., \& Pesonen, J. (2016). Impacts of peer-to-peer accommodation use on travel patterns. Journal of Travel Research, 55(8), 1022-1040.

Quinby, D., \& Gasdia, M. (2014). Share this! Private accommodation \& the rise of the new gen renter. Retrieved from http://www. phocuswright.com/Travel-Research/ConsumerTrends/ShareThis-Private-Accommodation-the-Rise-of-the-New-Gen-Renter

Xie, K. L., \& Kwok, L. (2017). The effects of Airbnb's price positioning on hotel performance. International Journal of Hospitality Management, 67, 174-184

Zervas, G., Proserpio, D., \& Byers, J. (2017). The rise of the sharing economy: Estimating the impact of Airbnb on the hotel industry. Journal of Marketing Research, 54(5), 687-705. 